\title{
Rethinking Borders: The Dynamics of Syrian Displacement to Lebanon
}

\author{
Filippo Dionigi \\ University of Bristol \\ f.dionigi@bristol.ac.uk
}

\begin{abstract}
Borders and territoriality are key components of modern forms of statehood, yet their relevance appears to be challenged by interstate movements of peoples. This essay proposes a reconceptualization of borders as "thin borders" to develop an analytical framework of the Syrian refugee crisis in Lebanon going beyond a conventional understanding of Westphalian statehood. Looking at historical and contemporary events, the analysis highlights several transborder dynamics influencing the process of refugees' displacement from Syria to Lebanon. It then illustrates the complex nature of borders as multilayered entities regulating the flow of people from Syria to Lebanon in a way that transcends the idea of national territoriality.
\end{abstract}

\section{Keywords}

Lebanon - Syria - refugees - borders - territoriality - statehood

Statehood, sovereignty and thus borders and territoriality have been called into question by the 2011 uprisings across the Middle East. ${ }^{1}$ The subsequent conflicts have fragmented Syria, Libya, Yemen, and Iraq, generating a vacuum for non-state actors to assert their presence. ${ }^{2}$ Forced migrations from these

1 Raffaella A. Del Sarto, "Contentious Borders in the Middle East and North Africa: Context and Concepts," International Affairs 93, no. 4 (2017). This research was partly funded by the Leverhulme Trust, Grant ECF 2014-675, and the Middle East Centre of the London School of Economics and Political Science.

2 Ariel I. Ahram and Ellen Lust, "The Decline and Fall of the Arab State," Survival 58, no. 2 (2016); Peter Harling and Alex Simon, "Erosion and Resilience of the Iraqi-Syrian Border," EUI working Papers RSCAS 2015, no. 61 (2015). 
conflicts, especially Syria's, have displaced millions within and across state borders.

No major structural change as understood by mainstream international relations theory has yet occurred. As Salloukh observes, the "return of the weak Arab state" creates the conditions for revitalized transnational connections. ${ }^{3}$ Yet, old regimes have fought back virtually everywhere supported by external regional and global allies preserving the status quo ante. ${ }^{4}$ But an appraisal of the dynamics that have shaped the region since 2011 can no longer rely on conventional Westphalian assumptions of statehood and borders.

Thinking of states as self-enclosed, national, territorial, and sovereign entities, inhibits understanding of the dynamics cutting across domestic, regional, and global spheres in the forms of popular uprisings, war, and migrations. The region has witnessed military interventions from outside into domestic contexts such as those in Libya, Bahrain, Yemen, and Syria. Conversely, phenomena such as social movements, militias, migrations, and economies have spread rapidly beyond domestic borders. Weakened by popular uprisings, war, and mass displacement, the state as an autonomous institutional order has been confronted by a dense web of transborder relations raising questions over the nature of its territoriality and its capacity to act as a "society container." 5,6

This essay proposes a reconceptualization of borders to provide a more accurate analysis of the nature of transborder dynamics, especially as concerns forced displacement. It proposes an analysis of the nature of borders between Syria and Lebanon through an adaptation of the concept of "thin border" focusing on people displacement from Syria to Lebanon. ${ }^{7}$ Thin borders are characterized by greater permeability to flows of peoples and things, but retain their regulative function. A thin border is not an equivalent for absence of border or "open" border; but refers to formal or informal regimes of crossings that "filter"

3 Bassel F. Salloukh, "Overlapping Contests and Middle East International Relations: The Return of the Weak Arab State," Ps: Political Science \& Politics 50, no. 3 (2017).

4 With the exception of Tunisia, where nevertheless revolutionary change has been slow, partial, and suffered several setbacks.

5 John Agnew, "The Territorial Trap: The Geographical Assumptions of International Relations Theory," Review of International Political Economy 1, no. 1 (1994).

6 Michael Mann, "The Autonomous Power of the State: Its Origins, Mechanisms and Results," European Journal of Sociology 25, no. 2 (1984).

7 This elaboration on the concepts of thin and thick borders partly relies on its theorisation in the disciplinary field of Planning Theory by Beatrix Haselsberger, "Decoding Borders. Appreciating Border Impacts on Space and People," Planning Theory \& Practice 15, no. 4 (2014). 
the flow of people or things through a set of constitutive layers. ${ }^{8}$ Haselsberger identifies these layers as political, cultural, economic, and physical "boundaries" forming the complex nature of the border. Whereas thin borders establish a regime of crossings for people and things, "thick" borders instead limit the possibility for trans-border transactions. ${ }^{9}$ The case of the Syrian refugee crisis in Lebanon is an opportunity to operationalize border thinness proposing an alternative perspective to explanations of displacement as merely dependent on geographical proximity.

\section{Explaining Border Thinness between Lebanon and Syria: A Boundaries Analysis}

Until 2015, the Lebanese-Syrian border has been an example of thin border because all its boundaries - political, economic, cultural, and physical - have been regulated in a way that has allowed a regular flow of people and goods.

The political boundary between these two states has always been very thin. Historically, at the times of the Ottoman Empire, the territories of Lebanon and Syria did not exist, and were divided in wilayat that subsequently became part of the same political project of Greater Syria. During the French Mandate, however, two related territorial entities were constituted which subsequently became Lebanon and Syria.

The project of "Greater Syria" has survived in the imaginary of political groups both in Lebanon and Syria. On this basis, the Syrian government and some of the Lebanese Panarabist factions have challenged the sovereignty and independence of Lebanon since its origins. Debates on Lebanon's national identity have often featured two main views between Lebanon's particularists such as Michel Chiha and Pansyrians as Antoun Sa'ade. ${ }^{10}$ The 1958 civil unrest was primarily a clash regarding Lebanon's stance towards the United Arab Republic highlighting the tensions that these opposing views have generated

8 Marc Lynch, "The Political and Institutional Impact of Syria's Displacement Crisis: Symposium Introduction," Middle East Law and Governance 9, no. 3 (2017), pp. 223-231.

9 Haselsberger 2014.

10 Kais M. Firro, "Lebanese Nationalism Versus Arabism: From Bulus Nujaym to Michel Chiha," Middle Eastern Studies 40, no. 5 (2004); Michelle Hartman and Alessandro Olsaretti, “The First Boat and the First Oar': Inventions of Lebanon in the Writings of Michel Chiha," Radical History Review 2003, no. 86 (2003). See also Filippo Dionigi, "Statehood and Refugees: Patterns of Integration and Segregation of Refugee Populations in Lebanon from a Comparative Perspective," Middle East Law and Governance (2017). on Lebanon's geopolitical uncertainty. 
in both countries. ${ }^{11}$ Since 1976 and for the following decades the Syrian regime disputed Lebanon's sovereignty with military intervention and occupation in Lebanon.

In the late nineties and the 200os, Lebanese nationalism took the form of a widespread anti-Syrian sentiment, which eventually coalesced in the March 14 multi-party alliance between Christian and Sunni political groups. In 2005 following a campaign of murders targeting Lebanese figures critical of the Syrian regime and in the wake of popular mobilization, the March 14 movement achieved the formal withdrawal of Syrian forces from Lebanese territory. Yet, Lebanese dissent towards Syrian influence has been offset by political groups such as AMAL, Hezbollah, and the Syrian Socialist Nationalist Party, which maintain close relations with the Syrian regime and see it a as a benevolent actor in Lebanon and the region.

The long-term relations of Syria and Lebanon blur the distinction between an exclusively Lebanese political sphere and a Syrian political context and instead show that the Syrian-Lebanese political boundary is thin. The political spaces of Syrian and Lebanese affairs have often overlapped and clashed generating long-term phases of reciprocal political influence or even direct control. Instead of clearly demarking the end of one political space and the beginning of another, the Lebanese-Syrian political boundary is a place of contestation with limited capacity to contain the objectives and ambitions of power holders on both sides.

Other examples highlight the nature of this phenomenon; for instance Syria opened an embassy in Lebanon only in 2008 thus formalizing diplomatic relations only at that point, and perhaps even more tellingly, the demarcation of the Lebanese-Syrian borderline is currently incomplete. ${ }^{12}$

The cultural boundary between Syria and Lebanon shows equally interrelated characteristics across the two countries. Similarly, to the rest of the region, common language, shared historical experience (such as the Ottoman past, the colonial experience or the Arab Israeli conflict), as well as religious connections, have weaved cultural relations between these two states. Epitomizing his Pansyrian stance, Hafez al-Asad used to describe provokingly the Lebanese and the Syrians as "one people in two states".13

11 Fawaz Gerges, "Lebanon," in The Cold War and the Middle East, ed. Avi Shlaim and Yazid Sayigh (Oxford: Oxford: Clarendon Press, 1997).

12 Emma Lundgren Jörum, Beyond Syria's Borders, (London: I.в. Tauris, 2017), 59.

13 Ihsan Hijazi, "Syria-Lebanon Cooperation Pact Signed," The New York Times 23 May 1991, http://www.nytimes.com/1991/05/23/world/syria-lebanon-cooperation-pact-signed .html. 
As in the case of the political context, cultural connections have also been challenged, for example some Christian factions which have promoted Lebanon's cultural specificity with reference to its Phoenicians heritage or by claiming exclusively Christian Maronite religious roots. ${ }^{14}$ Later on, other forms of cultural distinction have emerged, the slogan "Lebanon First" - adopted by anti-Syrian groups as al-Mustaqbal after 2005 - epitomizes the will and interest of some social and cultural milieus of Lebanon to differentiate themselves from Syria also on a cultural level. ${ }^{15}$

Other cultural contacts between Syria and Lebanon contribute to LebanonSyria border thinness. Links connect the Shia community of Lebanon and holy places for Shiism in Syria such as the Sayida Zayneb's shrine in Damascus. ${ }^{16}$ The Alawi population of the city of Tripoli maintain a special relationship with their coreligionists in Syria. ${ }^{17}$ There are portions of territory in which family connections cut across borders especially in the norther region of the 'Akkar, an area that enjoys a close proximity with Syria. ${ }^{18}$ The identification of Beirut as a more liberal cultural context compared to the traditionally Arab heritage of Syria constitutes a cultural distinction between these two cultural spaces, but also establishes a complementarity. ${ }^{19}$ For example, the newspapers of Lebanon have hosted the views of intellectuals that could not express their opinions in Syria, acting as the vent of cultural and social activities repressed in Syria. ${ }^{20}$ These examples are indicative of several forms of interaction and overlapping on social and cultural levels between these two spaces. While maintaining distinctiveness, Syria and Lebanon cultural boundary does not have the function of containing unrelated cultural spaces and instead is characterized a historically rooted flow of relations that makes it thin.

14 Kais Firro, Inventing Lebanon: Nationalism and the State under the Mandate (London: London: I.в. Tauris, 2003); Hartman and Olsaretti, "The First Boat and the First Oar': Inventions of Lebanon in the Writings of Michel Chiha."

15 Hannes Baumann, Citizen Hariri:Lebanon's Neoliberal Reconstruction (London: I.B. Tauris, 2017), 179 .

16 Albert Hourani, "From Jabal 'Amil to Persia," Bulletin of the School of Oriental and African Studies, University of London 49, no. 1 (1986).

17 Raphael Lefèvre, "Lebanon's Alawites at a Crossroads," Diwan (2014), http://carnegie-mec .org/diwan/55663.

18 Michael Gilsenan, "Lebanon's Gateway to Syria: Akkar before the Civil War," Middle East Report, no. 162 (1990).

19 Samir Khalaf, Lebanon Adrift: From Battleground to Playground (London: London: Saqi Books, 2012).

20 Samir Khalaf, Civil and Uncivil Violence in Lebanon: A History of the Internationalization of Communal Contact, The History and Society of the Modern Middle East (New York: Columbia University Press, 2002), 211. 
The Syrian-Lebanese economic boundary is probably the thinnest layer of the border structure. Between Lebanon and Syria there has always been an intense economic exchange on several levels. Syria has been for decades one of the main recipients of Lebanon's exports in competition with countries as Saudi Arabia, the UAE, and Iraq. For example, for the past twenty years, exports from Lebanon to Syria have oscillated between seven to ten percent of Lebanon total exports, making Syria among the top five recipients of its export. Syria is also a country of transition for the other destinations of Lebanon exports such as Saudi Arabia and the UAE, which can be reached by land only by crossing the border with Syria given the fact that the border with Israel is closed. ${ }^{21}$

Exports from Syria to Lebanon are not as significant but other forms of economic relations link the two countries. According to Andrew Tabler, Lebanon has been the "Piggy Bank" of Syrian businessmen for a long time. The banking services of Lebanon constitute an important resource for Syria which, since the rise to power of the Baath in 1963 , has nationalized its banks while Lebanese private financial institutions have offered world-famous secrecy and protection for Syrians business for a long time. ${ }^{22}$ Syrian-Lebanese economic relations are also connected through dynamics of labor mobility. Lebanon has been the recipient of hundreds of thousands of Syrian migrants who, for decades, have constituted a key resource for the labor intensive economic sectors, such as construction and agriculture. ${ }^{23}$ Conversely, Syrian workers have been an important source of remittances for Syrian families back home, thus reinforcing the economic bond between the two countries.

Sealing Lebanon's economic relations with Syria is the 1992 Treaty of Brotherhood and Cooperation imposed on Lebanon in the post-Tāef era. ${ }^{24}$ Among its accessory protocols the Agreement for Economic and Social Cooperation and Coordination states the objective of reaching economic integration between the two countries and establishes a set of measures for the free circulation

21 Data from the World Bank, World Integrated Trade Solutions online database, see http:// wits.worldbank.org/.

22 Andrew Tabler, "The Economic Relationship: Beyond All Political Fallout, the Economies of Syria and Lebanon Remain Deeply Intertwined and Complimentary," Executive (2005), http://www.executive-magazine.com/economics-policy/the-economic-relationship.

23 The number of Syrian workers in Lebanon is debated and fluctuates between 300000 and 600000 see John T. Chalcraft, The Invisible Cage: Syrian Migrant Workers in Lebanon, Stanford Studies in Middle Eastern and Islamic Societies and Cultures (Stanford, Calif.: Stanford University Press, 2008).

24 United Nations Treaty Series, "Treaty of Brotherhood, Cooperation and Coordination between the Syrian Arab Republic and the Lebanese Republic," ed. United Nations Treaty Collection (Beirut: UN, 1992). 
of goods and people across the border with minimal administrative burdens: it formalizes a regime of exchange between the two countries. ${ }^{25}$

A final point relates to informal trade. All the data available from official sources only refers to recorded transactions, yet the high informality of the economic sector in both countries entails that economic relations between these two countries are characterized also by a significant informal activity which further expands the volume of transactions and economic relations between the two states. Economic relations between Lebanon and Syria show how the economic boundary between these two has been constantly crossed by forces that tend to blur the distinction between two separate economic spheres and instead point towards a process of closer interaction. This renders also this boundary a particularly thin component of the Syrian-Lebanese border.

The fourth border dimension of the analysis concerns the physical boundary. The Lebanese-Syrian territory in its frontier areas is mainly characterized by the mountainous reliefs of the Anti-Lebanon. The underdeveloped infrastructure and the relatively challenging environment have had the effect of channeling border activities to four official crossing points, the most important of which is Masna'a. ${ }^{26}$ The northern border area is less mountainous and more directly connected with Syria. The rugged terrain of these areas means also that smuggling activity and informal crossing from both sides can take place unnoticed due to the difficulty of policing the region. Recent developments however have enhanced the capacity of the Lebanese Armed Forces to control this part of the territory. ${ }^{27}$ Overall, the physical character of the territory does not constitute a significant impediment to border crossing activities.

The overview of all four constitutive layers of the Syrian-Lebanese border shows how each of these are characterized by social, political, historical, and economic relations that highlight a remarkable contiguity between Lebanese and Syrian spaces. Some sectors of society - especially in Lebanon - have vociferously advocated a sharper differentiation between the two countries, but at least until 2015 a fluid border situation has prevailed over alternative forms.

Dissecting the border in its constitutive boundaries allows for an analysis of its structure that goes beyond a simple conceptualization of border as

25 Syrian Lebanese Higher Council, "Agreement for Economic and Social Cooperation and Coordination between the Lebanese Republic and the Syrian Arab Republic," (1993), http://www.syrleb.org/docs/agreements/o3SOCIAL_ECONOMICeng.pdf.

26 Masn'a, Mashar'i Al-Qa'a, al-'Aboudieh, al-'Arida, the crossing point of al-Amani in the north is also open but not acknowledged officially.

27 Simone Tholens, "Border management in an era of 'statebuilding lite': security assistance and Lebanon's hybrid sovereignty," International Affairs 93, no. 4 (2017). 
linear territorial delimitation state's space. Instead, it illustrates its complexity showing dynamics of space bordering characterized by significant interaction between the two states.

\section{Border Thinness during the Syrian Crisis}

The events of 2011 have challenged these established patterns of the SyrianLebanese border. Looking at the performance of the border, as a thin border, under the pressure of the Syrian humanitarian crisis provides an alternative analytical framework to understand the dynamics of displacement of Syrians to this country.

Lebanon has become the recipient of the highest concentration of Syrian refugees compared to the other neighboring countries. Whereas the country is geographically close to Syria, geographic proximity is not the main explanation for the dynamics of Syrian displacement. Israel, also adjacent to Syria has received virtually no refugee, thus showing that social and political dynamics play an important role in the identification of places of destination for refugees. Lebanon did not constitute the ideal destination for a population in search of security and sustainable livelihood. Some Lebanese political and military actors - above all Hezbollah - have close relations with the Syrian government; similarly, other political groups sympathize with Syrian opposition groups. The Lebanese economy, unemployment, and the insufficient infrastructure can hardly be attractive for refugees.

The political boundary level of analysis presents interesting aspects. Border thinness in this case means that Lebanese political actors have had direct stakes in the Syrian conflict that caused repercussions on the Lebanese context.

Lebanese political actors close to the Syrian regime, in particular Hezbollah, have intervened in the conflict directly dispatching troops and military support. The closure of the border with Syria is unconceivable for its very nature of thin border. In a speech of 2013, when Syrian displacement to Lebanon was beginning to grow, Hezbollah's secretary general Nasrallah observed that "we, as Lebanon, cannot close the border with Syria, with our understanding of the political, security and economic risks for this massive displacement."28

28 Anne Barnard, "Hezbollah Chief Urges Lebanon to Help in Syrian Crisis," The New York Times, 3 January 2013. 
Al-Mustaqbal, the leading group of the March 14 alliance, instead, capitalized on the situation to voice criticism towards the Syrian regime and - especially in the early phase of the uprisings - it expected the imminent fall of Bashar al-Assad's regime.

For the critics of the Syrian regime in Lebanon, the flow of Syrian refugees was a useful display, powerfully demonstrating the repression of the regime against its own people. This message was particularly persuasive at times in which the Arab public was galvanized by the anti-authoritarian protests taking place across the region which already ousted old-time dictators as Ben 'Ali, Mubarak, and Saleh.

Furthermore, the fact that the greatest majority of Syrians fleeing Lebanon could be identified as Sunni, has consolidated the connection between the al-Mustaqbal movement and Syrian refugees. The confessional politics of Lebanon combined with the growingly sectarian tones of the Syrian crisis converged.

The authorities did not need to undertake special measures to allow refugees into Lebanon; Syrians could cross freely into Lebanon officially and unofficially thanks to the pre-existing loose border regulations. ${ }^{29}$ The only part of the Syrian population that has faced restraints to enter Lebanon were the Palestinians of Syria, who were allowed to enter only at a later stage and on condition of settling in Palestinian camps. For Palestinians, the political boundary represented a limitation for their flight to safety, because contrarily to the Syrian case, Lebanese actors have not had interests in engaging with Palestinian politics for a long time. ${ }^{30}$

The thinness of the political boundary thus created a favorable condition for the movement of Syrians to Lebanon, because most of the actors had clear stakes in the events taking place in Syria and refugees' displacement was a phenomenon playing into broader political dynamics. Simultaneously with the unfolding of the Syrian crisis, Lebanese politics begun to experience a paralysis that brought about the postponement of general elections for two times, the vacancy of the presidential office from May 2014 to October 2016, and the

29 See Lama Mourad, “Inaction as policy-making: Understanding Lebanon's early response to the refugee influx" Middle East Law and Governance 9, no. 3 (2017), pp. 249-266

As a matter of fact, Lebanese politics has been deliberately discriminating against Palestinian refugees for a long time at this point due to the traumatic experience of the civil war. See A. Knudsen, “Widening the Protection Gap: The 'Politics of Citizenship' for Palestinian Refugees in Lebanon, 1948-2008," Journal of Refugee Studies 22, no. 1 (2009); Rex Brynen, "The Politics of Exile: The Palestinians in Lebanon," Journal of Refugee Studies 3, no. 3 (1990). 
change of four governments since 2011 intermitted by long phases of transition. The main exception were Christian political groups, in particular the Free Patriotic Movement, which has voiced criticism towards Syrian refugee presence since the beginning; but due to the political paralysis in Lebanon and their limited political leverage they could not influence governmental decisions on this matter until the end of 2014, when border restrictions were enacted.

As regards the thinness of cultural boundaries, these turned out to be an important asset for Lebanese political factions that advocated for an open border policy. The thinness of the cultural boundary allowed to frame ${ }^{31}$ refugee presence into their political discourse as religious responsibility, or inter-Arab brotherhood, or as hospitality due to kinship. For Lebanese Sunni groups as alMustaqbal, religious identity and their anti-regime stance aligned, establishing a direct connection with Syrians fleeing into Lebanon. Syrians are referred to as "brothers" in need, protesting against and fleeing from a regime that their Lebanese counterparts equally resent of, and this establishes a responsibility towards them. In 2011, a member of al-Mustaqbal for example declared that: "It is the responsibility of the government to guarantee for the [Syrian refugees] a safe place and for them to come into Lebanon to their families and neighbors without being attacked by any security or civil party."32

From a different perspective, but with the same effect, Hezbollah and AMAL have justified openness towards Syrian refugees as "humanitarian responsibility" and reciprocity. In a public speech, Hezbollah's secretary general Nasrallah described the situation as follows: "We should deal with the Syrian refugees with purely humanitarian responsibility, without politicization of the issue. Attention must be paid to the displaced families, whatever their political background."33

In a more localized perspective, small communities on the border, for example in the 'Akkar region of the north, have justified their reception to refugees in terms of "hospitality", as related to familial connections with Syrians across the border, although this form of hospitality has been also buttressed by the availability of international aid for both refugees and host communities. ${ }^{34}$

31 I am referring here, broadly, to the concept of framing as present in Social Movement Theory applied in this case to mobilization in support of refugee presence. See for example: David A. Snow et al., "Frame Alignment Processes, Micromobilization, and Movement Participation," American Sociological Review 51, no. 4 (1986).

32 "Lebanese Party Visits Syrian Refugees," B Bс Monitoring Middle East, 14 November 2011.

33 Barnard, "Hezbollah Chief Urges Lebanon to Help in Syrian Crisis."

34 Estella Carpi, "Refugee Hospitality and Humanitarian Action in Northern Lebanon: Between Social Order and Transborder History," in Humanitarian Aid on the Move (Beirut: Groupe U.R.D., 2016). 
Epitomizing the thinness of the cultural boundary especially in the northern region is a quote from a report in the early days of the crisis in June 2011, when the movement of refugees began from the areas of Talkhalak and al-'Arida:

There is no demarcation line between the borders of northern Lebanon and Syria. Inter-marriages between the people who live in between the two regions are common therefore; they have family ties in the villages and towns in the northern areas of Lebanon. As a result, most of the displaced Syrians had stayed with family and other relatives once they have crossed the border into Lebanese territory. ${ }^{35}$

In this case the framing of the humanitarian situation has not been related to the political nature of the protests in Syria, and instead public discourse could cite religious, cultural, kinship and historical relations as justifications of Syrian presence in Lebanon, associated with the fact that the Lebanese enjoyed Syrians' protection in times of war and shared a common history of displacement during the conflicts with Israel and the civil war.

Border thinness also related to economic dynamics. The economic boundary with Syria has remained open and operative during the conflict. Although the availability of data is intermittent and does not cover abundant informal activities; Lebanon did suffer an economic setback but it is not obvious to claim that this is related only to the Syrian refugee crisis. At least until 2015 Lebanon's exports to Syria increased, whereas the imports have decreased, thus the balance of trade in fact turned in favor of Lebanon. There have been phases of border closures, and the fact that the Jordanian border with Syria has been closed has slowed down trade, but overall the Syrian-Lebanese boundary has remained a vital economic channel. ${ }^{36}$

The thinness of the economic boundary depends also on the fact that hundreds of thousands of Syrian workers have been employed in Lebanon for decades. This has played a significant role in the dynamics of their displacement. In a meeting with the author, for example, the mayor of a small municipality in the Biqaa Valley has indicated that many of the Syrians that resettled in his area had previous experience of working there. According to a rough estimate, he claimed that about ten per cent of the Syrians in his municipality had previous experience of working in Lebanon. This may seem a relatively limited amount but the mayor then explained that, differently from the pre-crisis

35 International Medical Corps, "Psychosocial Assessment of Displaced Syrians at the Lebanese-Syrian Northern Border," (Beirut: International Medical Corps, 2011).

36 Massimilano Calì et al., "The Impact of the Syrian Conflict on Lebanese Trade," in World Bank Reports (Washington: World Bank, 2015). 
years, this time Syrian workers brought their families with them. This has a multiplying effect: each Syrian worker/refugee also had a family group with him relocating to Lebanon. ${ }^{37}$ The International Labour Organization observes that of a sample population of economically active Syrian refugees, twenty per cent of them had previous experience of employment in Lebanon, and that having worked in Lebanon before increases the chances of finding a job while relocating to Lebanon. ${ }^{38}$ The thin economic boundary, played a role in shaping the dynamics of displacement because the economic relations that existed before the crisis established a degree of path-dependency for Syrians to relocate to an area in which they previous experience of work.

Finally, as concerns the physical boundary, the fact that the border regions of Lebanon with Syria are characterized by a conformation of territory that is difficult to monitor has facilitated the informal access of Syrians to Lebanese territory. This has also caused the reverse phenomenon whereby Syrians could travel back and forth from their country usually to check on their property or for short trips to their place of origin.

Conceptualizing borders not as simple territorial demarcations but as complex multi-layered entities allows illustrating the conditions that have generated a process of displacement unprecedented for speed, intensity, and magnitude. The thin political boundary between Lebanon and Syria let the repercussions of the conflict reverberating directly in the Lebanese political context. Cultural connections have provided most political actors with the opportunity to frame refugee presence in discourses of hospitality towards Syrian refugees. A history of economic relations and labor transfer has constituted a migratory imprint which some refugees have used as compass for their relocation. Finally, the physical boundary has rendered border policing more difficult and then informal crossing easier.

Whereas geographic proximity between the two countries is an influential aspect, border thinness explains the modes, contexts, and selectivity of Syrian displacement. The fast and robust flow of refugees as well as the unwillingness and incapability to close the border, show that an idea of territorialized state and society contained by nationalized borders hardly applies especially at a point in which the Syrian state is weakened by a devastating crisis. Instead, the closely connected political, cultural, and economic spaces of Lebanon and Syria constitute a space for interaction between refugees, political elites, and host communities that transcend state territoriality.

37 Nizam Saleh Rais al-Baladiya al-Marj (Lebanon), interview by Filippo Dionigi, 21 May 2015 .

38 Sawsan Masr and Ilina Srour, "Assessment Fot He Impact of Syrian Refugees in Lebanon and Their Employment Profile," (Beirut: ILo Regional Office for Arab States, 2013), 23. 


\section{Thickening the Border}

The Syrian uprisings turned into a conflict where not only domestic forces clashed but also regional and global actors intervened. The possibility of a quick transition in power, expected by al-Assad's critics and feared by his allies, vanished. The change from uprising to protracted conflict, transformed the perception of its repercussions within the Lebanese context. The critics of al-Assad's regime in Lebanon became less interested in tying their politics to the conflict in Syria, thus assent to the presence of Syrians in Lebanon became less prominent. By 2013, Syrian refugee presence had begun to exact a price in political capital, since local administrations were increasingly affected by the demographic pressure.

In April 2014, the UNHCR reported the registration of more than a million Syrian refugees, roughly equivalent to one quarter of Lebanon's autochthonous population. The picture became even more complex in June 2014, when the Syrian regime held presidential elections. In that occasion, tens of thousands of Syrians marched towards the Syrian embassy in Beirut, chanting pro-regime slogans in a show of support for the regime. ${ }^{39}$ The political forces opposed to the Syrian government - and keener to acquiesce to Syrian refugee presence - were surprised by this display of support for the regime..$^{40}$ The changed perception of refugee presence, eventually precipitated a policy change over border regulation.

In October 2014, Lebanon's council of ministers adopted a new policy proposed by Christian party leaders and endorsed by most political groups the main purpose of which was restricting access to Lebanese territory and creating an incentive for Syrians to leave Lebanon. ${ }^{41}$ The decision of the council, implemented in January 2015, made harder and more expensive the renewal of residency permits for refugees in Lebanon. In addition, the border crossing was de facto forbidden to Syrians in humanitarian need. For the first time in decades in Lebanese-Syrian relations, a regime of border restriction was

39 Jim Muir, "Syria Election: Refugees Vote in Lebanon and Jordan," ввс, http://www.bbc .co.uk/news/world-middle-east-27599868.

40 Following the election, the general secretariat of March 14 even released a declaration calling for the deportation of those Syrians that have participated to the mobilization in occasion of the electoral consolation. Now Lebanon, "March 14 Officials Request Deportation of Pro-Assad Syrians," Now Lebanon, https://now.mmedia.me/lb/en/ lebanonnews/549157-march-14-officials-request-deportation-of-pro-assad-syrians.

41 Presidency of the Council of Ministers, "2014 جلسة 23 تشرين الأول [Session of the 23 October 2014]," ed. Council of Ministers (Beirut 2014). 
activated; the Syrian ambassador to Lebanon protested that the decision was taken without the consensus of the Syrian government. ${ }^{42}$

The 2015 border policy is not a blanket closure but a filter that modulates entrance to Lebanon, in different ways for each of the constitutive boundaries of the Syrian Lebanese border. This measure marked a change in the nature of the Syrian-Lebanese border but not a full closure across all its boundaries. For example, Syrians are admitted if they can demonstrate that they travel for business, if they are sponsored by an employer, if they own assets in Lebanon, such as real estate, or if they have travel documents or a hotel booking which demonstrate their transit in the country.

The political boundary at this point has "thickened" because - disillusioned by the outcome of the uprisings in Syria - the critics of the Syrian regime in Lebanon had less interest in projecting their influence on the dynamics of the conflict across the border. The only political actor that has remained fully committed to shaping the Syrian conflict is Hezbollah, which - in spite of any border restrictions - has kept moving freely its troops and armaments across the border. For most others, isolating from it was in their best interest and that of their constituencies, now that the demographic pressure has reached a limit and the loyalty of the refugees to the anti-regime camp was not as clear-cut.

The cultural boundary witnessed a parallel process, whereby the rhetoric of solidarity, hospitality, and brotherhood has been progressively outdone by a sense of fatigue, the exacerbation of sectarian dynamics, and the intensification of a "Lebanese Vs Syrian" public discourse especially within local administrations. ${ }^{43}$ Some indicators are phenomena such as the curfews targeting the mobility of Syrian refugees, or the intention to strip Syrians of their status of "displaced" when travelling back and forth from Syria. ${ }^{44}$ Political interests and the narrative of hospitality and responsibility in which it was previously

42 Molly Hennessy-Fiske and Nabih Bulos, "Lebanon's New Visa Rules for Syrians Aim to Curb Refugee Influx," Los Angeles Times 5 January 2015, http://www.latimes.com/world/ middleeast/la-fg-lebanon-syria-visas-20150105-story.html.

43 The possibility of a spill over of the Syrian conflict in Lebanon has materialised in a stream of attacks with a clear sectarian tone that has hit the country in several occasions. Furthermore, a confrontation emerged between a rising Salafist and sectarian movement and militia headed by a Sheikh Ahmad al-'Asir, which has been subsequently repressed and his leader arrested. These episodes nevertheless remain sporadic and failed to ignite a conflict on a sustained scale.

44 Human Rights Watch, "Lebanon: At Least 45 Local Curfews Imposed on Syrian Refugees," Human Rights Watch, http://www.hrw.org/news/2014/10/03/lebanon-least-45 -local-curfews-imposed-syrian-refugees; Now Lebanon, "Derbas: Return Trips to Syria Contradict Refugee Status," Now Lebanon (2014), https://now.mmedia.me/lb/en/archive/ 549101-derbas-return-trips-to-syria-contradict-refugee-status. 
framed misaligned and a sharper distinction between a Lebanese and Syrian space emerged.

In contrast with political and cultural boundaries the measures of 2015 did not apply to the economic boundary, that was left deliberately thin. Given the economic interdependence between the two states - especially as concerns trade and labor - this is not surprising. As mentioned above, reasons such as business, trade, or work sponsorships, allowed for the circulation of Syrians. The selectiveness of this policy then shows how border policy can be arranged differently across its boundaries: border policies can rarely be captured by simple "open or close" descriptions.

The physical boundary cannot be easily modified unless by building fences or through surveillance devices that modify the boundary in its physical possibility to be crossed. The Lebanese government has been progressively reinforcing its surveillance along the border - also thanks to military aid and training from international donors - but the new measures of 2015 have not modified the physical boundary significantly.

The result of the 2015 policy change is a disarticulation of the structure of the border from one that was equally thin across all its layers, and receptive of Syrians in general, to a form of border filtering which has rendered crossing difficult for Syrians in humanitarian need. Also the renewal of residency permits for refugees already present in Lebanese territory has been made more laborious. Intensified bureaucratic procedures have been introduced including the production of official documents concerning the place of residence of refugees, and harsher measures prohibiting their employment.

Consequently, Syrians have been increasingly pushed outside political and cultural boundaries, while those who had an economic status could still take advantage of the thinness of the economic boundary. These new measures, therefore, failed to effectively raise a thick border between the Syrian and Lebanese context in two ways. The first is that border crossing is limited but still possible when meeting certain, primarily economic, conditions. The second and more important aspect is that the heavily bureaucratized residency renewal procedures did not constitute an incentive for return or relocation of Syrians. Instead, this measure has pushed the greatest majority of the population into a condition of "irregularity" due to the fact that many could not renew their residency permits.

This situation prefigures not the creation of separate territorial spaces as it would be expected by the rise of effective international borders - but the development of other forms of overlapping and "liminal space". 45 Some Syrians 
can still take advantage of the scarce containment capacity of borders especially when economic conditions allow. On the other hand, Syrians already in Lebanon have been excluded through new regulation from their regular status in Lebanon, but -unable and unwilling to leave Lebanon - are still a physical presence in the Lebanese territory. This relegates them to a liminal space where they are not in Lebanon - as they are not legally within it - but they are not outside it, because they are within Lebanese territory and society. The 2015 regulation therefore, has failed to demarcate a thick border between Syria and Lebanon. In fact, it has generated a "borderland":46 an even more extensive space in which Lebanese and Syrians boundaries are indistinct.

\section{Conclusion}

Studying border thinness between Lebanon and Syria is a way of going beyond Westphalian assumptions on the state as a nationally, self-enclosed, territorially contained, sovereign entity. Instead it highlights how borders are instruments to project power beyond the domestic sphere of sovereignty from both sides. More broadly, this approach could shed light on the fast and fluid trans-border dynamics that have shaped Middle Eastern politics and society, especially since 2011, striking a balance between the overall dismissal of borders relevance and the adoption of a fully territorialized conception of the state.

The point, nevertheless, is not to make an exceptionalist argument about Middle Eastern statehood. As observed by Wendy Brown and others, the international order at large is increasingly post-Westphalian and the proliferation of walls as borders protection is symptomatic of the global waning of state territoriality and not of its return. ${ }^{47}$

What is unique is the historical and social context that has shaped the development of thin borders between Lebanon and Syria and between other Middle Eastern states; thinness which has been further magnified by the crisis of the Syrian state. In addition to the brutality of the conflict and the geographical proximity, border thinness is a factor explaining the magnitude and rapidity of the refugee crisis in Lebanon.

Borderlands: Boundaries in Depth and in Motion, ed. I. William Zartman (Athens: University of Georgia Press, 2010).

46 Agier, Borderlands.

47 Wendy Brown, Walled States, Waning Sovereignty (New York Cambridge, Mass.: Zone Books, 2010), 21. 
Politically, the Syrian events of 2011 and 2012 - given the broader context of a region in turmoil - resounded directly in the Lebanese environment making the thinness of the political boundary most evident. The thinness of the cultural boundary is clear in the process of framing of Syrian presence in Lebanon, it overrides nationalist objections to refugee presence, marking a sharp contrast with states (for example in the western hemisphere) where forced displacement has been used to ignite nationalist populism. The intense economic exchange between these two countries has constituted a robust pattern of interdependence that has inhibited restrictions on border crossings.

Yet borders, even thin borders, maintain a regulative function. Thin borders are not a euphemism for weak, open, or redundant border. They retain a filtering function, ${ }^{48}$ for instance in their discrimination against Palestinian Syrians. Furthermore, in 2015 Lebanon enacted measures that have changed the dynamics of flow especially with respect to Syrians in humanitarian need, adding further filtering to border crossing. Syrian who intended to cross into Lebanon for humanitarian reasons were discriminated against at the border, whereas those who were already in Lebanon or intended to travel to Lebanon for economic reasons could benefit from the fact that the economic boundary was kept thin by Lebanese authorities. This has produced a disarticulation of the border from general thinness to different degrees across different layers. Refugees unable to access Lebanon or to renew their residency permits have been relegated into a liminal space delimited at one end by the restrictions imposed by the 2015 regulation and by Syrian inhabitability on the other end. ${ }^{49}$ The political and cultural thickening of the boundary has isolated Syrian refugees and confined them to what Michel Agier would define a "borderland": an area where people cannot cross completely the border and therefore becomes a "border dweller" neither inside nor outside a country. ${ }^{50}$

The dynamics of forced displacement between Syria and Lebanon show how society, politics, and economics, are hardly contained within bordered state institutions and transcend this spatiality forming a web of relations which a conventional conception of territoriality fails to expose.

48 Marc Lynch "The Political and Institutional Impact of Syria's Displacement Crisis: Introduction."

49 To be noticed is the fact that in early 2017 the costs and procedures for the renewal of residency permits have been temporarily waived for Syrians already registered with UNHCR in Lebanon as part of an agreement between UNHCR Lebanon and the Ministry of Interior.

5o Borderlands in Lebanon and elsewhere can be extensive and densely populated, for example the condition of Palestinian refugees and that of tens of thousands of stateless individuals in this country very much resembles this status of suspension in between borders. Agier, Borderlands, 58 . 